\title{
UČINCI SUSTAVA OSIGURANJA DEPOZITA NA BANKOVNI RIZIK
}

\author{
Stella Suljić Nikolaj
}

Dr. sc., asistent, Sveučilište u Rijeci, Ekonomski fakultet, Ivana Filipovića 4, 51000 Rijeka, Hrvatska; e-mail: stella.suljic.nikolaj@efri.hr

\section{Bojana Olgić Draženović}

Dr. sc., docent, Sveučilište u Rijeci, Ekonomski fakultet, Ivana Filipovića 4, 51000 Rijeka, Hrvatska; e-mail: bojana.olgic.drazenovic@efri.hr

\section{Saša Drezgić}

Dr. sc., izv. prof., Sveučilište u Rijeci, Ekonomski fakultet, Ivana Filipovića 4, 51000 Rijeka, Hrvatska; e-mail: sasa.drezgic@efri.hr

\section{SAŽETAK}

Bankovna stabilnost temelji se na povjerenju deponenata u bankovne institucije i cjelokupni bankovni sustav. Jedna od bazičnih mjera koje osiguravaju navedeno je sustav osiguranja depozita kao sastavni dio sigurnosne mreže svakog financijskog sustava. Njegova važnost posebno dolazi do izražaja u uvjetima nestabilnosti i kriza, dok se u tzv. „dobrim vremenima“ podcjenjuju brojni pozitivni učinci. Ipak, sustav osiguranja depozita rezultira i negativnim posljedicama u smislu većeg preuzimanja rizika od strane banaka, smanjenja tržišne discipline, problema moralnog hazarda i negativne selekcije te problema principala i agenta. Cilj rada je ispitati učinke sustava osiguranja depozita na bankovnu stabilnost u tri razdoblja: prije globalne financijske krize, za trajanja krize i nakon krize. Bankovna stabilnost aproksimirana je mjerama bankovnog rizika (z-score, nenaplativi krediti u ukupnim kreditima). Istraživanjem su obuhvaćene sve vrste kreditnih institucija (ukupno 1453) zemalja članica EU-a i odabranih država II Europe. Analiza je provedena dinamičkom panel analizom - GMM Arellano-Bond ( $A B$ ) procjeniteljem u dva koraka. Rezultati empirijske analize ukazuju kako djelovanje sustava osiguranja depozita na bankovnu stabilnost mjerenu bankovnim rizikom ovisi o pojedinim obilježjima (karakteristikama) sustava odnosno o primijenjenom dizajnu sustava s obzirom na institucionalne, povijesne i pravne razlike među zemljama.

Ključne riječi: sustav osiguranja depozita, bankovna stabilnost, rizik, dinamička panel analiza. 


\section{UVOD}

Prvim nacionalnim, formalnim ${ }^{1}$ sustavom osiguranja depozita smatra se FDIC (Federal Deposit Insurance Corporation) sustav osnovan 1933. g. u SAD-u. Sustav je nastao kao odgovor na slom dioničkog tržišta (1929. g.) koji je uzrokovao propast više od 9000 banaka. Od tada je sustav osiguranja depozita uobičajen oblik zaštite deponenata koji dodatno osigurava stabilnost bankovnog sustava jer sprječava mogućnost „navale“ tj. „juriša“ na banke (engl. bank run). Unatoč navedenom pozitivnom djelovanju, efekti sustava osiguranja depozita nisu jednoznačni. Značajan broj teorijskih i empirijskih dokaza upućuju na negativne posljedice koje sustav osiguranja depozita može implicirati na bankovnu stabilnost i tržišnu disciplinu zbog problema moralnog hazarda, negativne selekcije te problema principala i agenta (Demirgüç-Kunt, Detragiache, 2002; loannidou, Penas, 2009; Angkinand, Wihlborg, 2010; Fonseca, González, 2010; Khan, Dewan, 2011; Lee, Hsieh, 2013; Fang et al., 2014). Efekti sustava osiguranja depozita na bankovnu stabilnost ovise o karakteristikama sustava koji bi trebali biti određena u skladu s nacionalnim zakonodavnim i regulatornim okvirom kao i razvijenošću bankovnog sustava.

Tablica 1. Obilježja sustava osiguranja depozita

\begin{tabular}{|l|l|}
\hline Osnovna obilježja & Dodatna obilježja \\
\hline Način osnivanja: eksplicitni/implicitni & Paybox plus² oblik zaštite \\
\hline Način rukovođenja sustavom: državni/privatni & Pokrivenost depozita u stranoj valuti \\
\hline $\begin{array}{l}\text { Vrsta fonda za prikupljanje sredstava: ex-ante/ex- } \\
\text { post }\end{array}$ & Pokrivenost međubankovnih depozita \\
\cline { 1 - 2 } Postojanje koosiguranja & $\begin{array}{l}\text { Podrška vlade u prikupljaju sredstava } \\
\text { bez obzira na rukovođenje sustavom tzv. } \\
\text { backstop }\end{array}$ \\
\hline $\begin{array}{l}\text { Premija sustava osiguranja depozita: diferencirana } \\
\text { rizikom („fer“ premija) / nediferencirana rizikom } \\
\text { (jednaka za sve institucije) }\end{array}$ & \\
\cline { 1 - 2 } Iznos zaštite depozita &
\end{tabular}

Izvor: prema Suljić et al. 2014.

S obzirom na sklonost banaka preuzimanju rizika, Calomiris (1999) ističe opravdanost elemenata sigurnosne mreže, koje osim sustava osiguranja depozita, uključuje i funkciju centralne banke kao pružatelja posljednjeg utočišta te regulaciju i superviziju banaka (Kundid, 2013). Prema Calomirisu i Wilson-u (2004) prvim motivom postojanja sigurnosne mreže smatra se održavanje bankovne kreditne funkcije što podrazumijeva opravdanost pružanja pomoći rizičnim bankama kako bi se spriječili društveni troškovi prema bankovnim zajmoprimcima zbog pada kreditne aktivnosti. Drugi

1 Povijesno gledajući, prvi sustav osiguranja depozita osnovan je u državi New York 1829. g., ali bez nacionalnih obilježja. U Europi je 1924. g. osnovan sustav osiguranja depozita u tadašnjoj Čehoslovačkoj.

2 Paybox ili isplatna funkcija jamči isplatu štedišama (deponentima) u slučaju propasti banke, a države se mogu odlučiti hoće li tom osnovnom modelu zaštite pridodati funkciju bankovnog supervizora ili makroprudencijalnog regulatora što predstavlja paybox plus oblik zaštite koji uključuje viši stupanj zaštite za deponente. 
motiv ističe važnost sustava osiguranja depozita u vrijeme krize s ciljem održavanja povjerenja u bankovni sustav te sprječavanja panike deponenata i povlačenja depozita iz banaka. Navedeno je potvrdila i globalna financijska kriza 2007/2008. g. koja je posljedično dovela do značajnih izmjena u sustavima zemalja EU-a.

Prije svega, sustavi osiguranja depozita država članica EU-a postali su „velikodušniji”3 (engl. generous deposit insurance system). Po izbijanju krizu 2008. g. došlo je do inicijalnog povećanja iznosa zaštite, a dvije godine kasnije ujednačio se je limit na 100000 eura za sve članice (osim Danske, Slovačke i Irske koje su primjenjivale neograničene iznose zaštite do kraja 2010. odnosno 2013. g.). Osim toga, sustavi su unaprijeđeni i uvođenjem dodatnih obilježja, primjerice paybox plus oblik zaštite i backstop podrška. Direktiva 94/19/EZ Europskog parlamenta i Vijeća EU-a predstavljala je podlogu minimalnog usklađivanja sustava osiguranja depozita članica EU-a jer je svaka članica imala dovoljnu slobodu prilagoditi direktivu obilježjima vlastitog bankovnog i financijskog sustava. Narušena bankovna i financijska stabilnost u razdoblju krize rezultirale su predstavljanjem prijedloga od strane Europske komisije 2012. g. za uspostavom europskog okvira (bankovna unija) kojim bi se sprječile i rješavale buduće bankovne krize (Direktiva 2014/49/EU). Bankovna unija kao nadnacionalni, institucionalni okvir za prevenciju kriza i bolje upravljanje kriznim situacijama sastoji se od tri stupa: jedinstveni mehanizam nadzora, jedinstveni sanacijski mehanizam i europski sustav osiguranja depozita (Olgić Draženović et al., 2017). Posljednjim elementom se sustavi osiguranja depozita nastoje objediniti prema svojim obilježjima, prije svega iznosom zaštite, ali i participiranjem svih kreditnih institucija unutar sustava osiguranja depozita, smanjenim rokovima isplate, kombinacijom ex ante i ex post fonda i sl. Stoga sustav osiguranja depozita nadilazi nacionalne potrebe zaštite bankovnog sustava odnosno njegova uloga usmjerena je na postizanje bankovne stabilnosti EU-a. Istraživanje je provedeno na uzorku država članica EU-a (28) te 6 država Jl Europe (Albanija, Bosna i Hercegovina, Crna Gora, Kosovo, Makedonija, Srbija). Istraživanja fokusirana na različite efekte koje sustav osiguranja depozita može imati na bankovnu stabilnost relativno su oskudna za zemlje EU-a, dok su nepostojeća za države Jl Europe, stoga je ovim istraživanjem ostvaren znanstveni doprinos u teorijskom i aplikativnom smislu.

Istraživanjem će se testirati znanstvena hipoteza: Obilježja/karakteristike sustava osiguranja depozita utječu na njegovu funkcionalnost u postizanju bankovne stabilnosti izražene kroz razinu preuzetih rizika banaka. Cilj istraživanja je istražiti teorijsku i empirijsku građu o značajkama sustava osiguranja depozita, procijeniti karakteristike sustava osiguranja depozita u članicama EU-a i državama JI Europe te istražiti i objasniti čimbenike bankovne stabilnosti te empirijski dokazati njihovu ovisnost.

Nakon uvoda, autori uvode u problem istraživanja pregledom teorijskih i empirijskih istraživanja. U trećem dijelu predstavljena je metodologija znanstvenog istraživanja. Zatim slijedi empirijska analiza i interpretacija rezultata empirijske analize. Na kraju su predstavljeni glavni zaključci rada.

3 Pojam velikodušnog sustava osiguranja depozita podrazumijeva jači oblik zaštite uz zastupljenost dodatnih funkcija sustava osiguranja čime se u razdoblju krize utječe na smanjenje navala na banke, a u razdoblju prosperiteta na veće preuzimanje rizika od strane banaka. Prema Cull et al. (2005) velikodušnim sustavom osiguranja depozita smatra se sustav s visokom pokrivenošću po deponentu ili koji pokriva širi izbor depozita (devizne i međubankovne depozite). Nastavno, velikodušni sustavi osiguranja depozita nemaju koosiguranje. 


\section{PREGLED LITERATURE}

Sustav osiguranja depozita predstavlja mjeru zaštite deponenata i bankovnog sustava, a njegova važnost očituje se u samoj činjenici da bankovna stabilnost u velikoj mjeri ovisi o povjerenju deponenata u bankovni sustav (Suljić Nikolaj, 2018). Za razliku od sustava osiguranja depozita, pojam bankovne stabilnosti teško je definirati. Razlog tome „proizlazi iz složene prirode financijskih sustava te postojanja složenih veza između različitih sektora" (Cerović et al., 2017, 248).

Prihvaćena teza prema kojoj razvijen i stabilan financijski sustav predstavlja preduvjet razvijenog gospodarstva, doprinosi značajnosti istraživanja bankovne i financijske stabilnosti. Prema Olgić Draženović i Kusanović $(2016,758)$ „financijski sustav neophodan je za svako nacionalno gospodarstvo jer njegov razvoj i učinkovitost podržava investicije i rast". lako se pojmovi bankovne i financijske stabilnosti često poistovjećuju s obzirom na veliki značaj banaka u financijskom sustavu, oni nisu istovjetni jer bankovna stabilnost predstavlja segment financijske stabilnosti. Financijska stabilnost prema HNB-u predstavlja ,jedan od ključnih preduvjeta održivoga gospodarskog rasta koji se očituje u nesmetanom funkcioniranju svih segmenata financijskog sustava u procesu alokacije resursa, procjene i upravljanja rizicima te izvršavanja plaćanja, kao i u otpornosti sustava na iznenadne šokove“. Schwartz $(1986,13)$ navodi kako se „financijska stabilnost ne može ostvariti bez prisustva bankovne stabilnosti te ujedno da ugrožena bankovna stabilnost dovodi do financijske krize". Stoga se definicija bankovne stabilnosti često izvodi iz pojma bankovne i financijske krize kao i sistemskog rizika. U znanstvenim istraživanjima, osim poistovjećivanjem s financijskom stabilnosti, bankovna stabilnost najčešće se definira kroz financijsku i bankovnu krizu te sistemski rizik.

Eksplicitni sustavi osiguranja depozita u odnosu na implicitne sustave nude viši stupanj zaštite te su karakteristični za razvijenije države (Prohaska et al., 2015). S druge strane, mnoga istraživanja (npr. Cull et al., 2002; Davis, Obasi, 2009; Lé, 2013; Ngalawa, 2016) dokazala su kako eksplicitni sustavi mogu stvoriti negativne efekte poput nestabilnosti bankovnog sustava i/ili kriza te povećanja moralnog hazarda banaka. Ipak, empirijski dokazi o povezanosti eksplicitnog sustava osiguranja depozita i povećanog preuzimanja rizika su nekonzistentni jer učinak ovisi i o vlasničkoj strukturi sustava osiguranja depozita kao i drugim institucionalnim karakteristikama.

Sagledavajući obligaciju učlanjenja, istraživanja preferiraju obvezno participiranje u sustavu. Prema Blair-u et al. (2006) dobrovoljno članstvo uzrokuje negativnu selekciju te povećava moralni hazard. Rukovođenje sustavom osiguranja depozita moguće je organizirati kao privatno, državno ili mješovito. Demirgüç-Kunt et al. (2007) zalažu se za privatni sustav upravljanja zbog veće objektivnosti u nadzoru od strane privatnih sudionika kao i bolje osposobljenosti u odabiru informacija potrebnih za upravljanje sustavom. U nešto ranijim istraživanjima Garcia (1999), Demirgüç-Kunt, Kane (2002) utvrđena je povezanost privatnog sustava osiguranja depozita s višim stupnjem razvoja države stoga je takav sustav zastupljeniji kod razvijenih država. Brandao-Marques et al. utvrdili su kako državni način upravljanja sustavom osiguranja depozita stvara moralni hazard i ima nepovoljan učinak na bankovnu stabilnost. S druge strane Diamond i Dybving (1983) smatraju kako je državni sustav osiguranja depozita učinkovitiji od privatnog iz razloga što su sredstva fonda kod privatnog sustava osiguranja depozita ograničena. Pennacchi (2006) je zaključio da je u vrijeme 
krize, državni sustav osiguranja depozita likvidniji (može prikupiti više potrebnih sredstava) od privatnog.

Fond sustava osiguranja depozita koji je potreban da bi se deponentima moglo isplatiti iznose njihovih sredstava ukoliko dođe do sloma banke, može biti osnovan unaprijed, ex-ante ili za vrijeme nastanka bankovnih poremećaja, ex-post. Pojedine države imaju tzv. mješoviti fond zbog prisutnosti i ex-ante i ex-post fonda, međutim klasifikacija Svjetske banke i mješovite fondove svrstava u ex-ante, zbog njegove dominacije. Potrebno je istaknuti da su empirijska istraživanja koja utvrđuju implikacije vrste fondova sustava osiguranja depozita na stabilnost bankovnog sustava, oskudna. Na uzorku od 150 država s eksplicitnim sustavom osiguranja depozita, u razdoblju od 1980. do 2003. g., Khan i Dewan (2011) dokazali su prisutnost veće mogućnosti za nastanak kriza kod eksplicitnih sustava ukoliko su organizirani kao ex-ante sustavi. Uz fond sustava osiguranja depozita, vezuje se i vrsta premije koje banke uplaćuju u fond. Rochet $(2008,230)$ ističe kako „pogrešno definiranje premije ovisno o količini depozita, a ne o sastavu imovine ili omjeru kapitala rezultira bankovnim neuspjehom". Acharya et al. $(2010,89)$ navode da efektivno postavljanje premije sustava osiguranja depozita u skladu s rizikom banaka, opravdava postojanje sustava osiguranja depozita. Pritom ističu kako su neki od glavnih čimbenika koji dovode do sustavnog rizika; „odnos između banaka, veličina banke te međusobno povezivanje banaka“, stoga ih je potrebno uključiti u formiranje premije sustava osiguranja depozita. Faulend i Kraft $(2004,126)$ zaključuju kako će diferenciranim obračunom premije, kreditne institucije biti potaknute voditi „relativno konzervativniju politiku plasmana, tj. kreirat će manje rizičan portfelj”. Suprotno tome, Goodman i Santomero (1986) su dokazali da naplaćivanje fer premije ne donosi najveću društvenu korist, jer je smanjenje društvenog troška propadanja banaka pri prelasku sa sustava jedinstvene stope na fer stopu premije osiguranja depozita, manje od povećanja društvenog troška koje bi ta promjena izazvala. Pennacchi (2006) je dokazao da u vrijeme krize fer premije dovode do duže nestabilnosti. Da bi sustav osiguranja depozita smanjio mogućnost moralnog hazarda, sustav može sadržavati koosiguranje koje podrazumijeva da je jedan dio iznosa depozita neosiguran s ciljem poticanja deponenata da nadgledaju poslovanje banaka. Iznos zaštite osiguranih depozita jedna je od najznačajnijih obilježja sustava osiguranja depozita. $U$ različitim je istraživanjima (npr. Chu, 2011; Demirgüç-Kunt et al., 2014; Chen et al., 2014) utvrđeno da su u stabilnom razdoblju viši iznosi osiguranih depozita karakteristični za slabije razvijene države, dok su za razvijene države sa stabilnim bankovnim sustavom karakteristični niži iznosi osiguranih depozita. Međutim, u razdoblju krize to pravilo ne vrijedi jer tada sve države zbog bojazni od nastanka panike i navale na banke, povećavaju iznose osiguranih depozita kao preventivnu mjeru (lyer et al., 2016).

\section{MODEL UTJECAJA SUSTAVA OSIGURANJA DEPOZITA NA BANKOVNU STABILNOST}

U empirijskom dijelu istraživanja i utvrđivanja djelovanja sustava osiguranja depozita na bankovnu stabilnost koriste se panel podaci odnosno longitudinalne varijable koje sadrže prostornu i vremensku dimenziju. Vremenska dimenzija istraživanja usmjerena je na godišnja opažanja u razdoblju od 2005. do 2014. g. Za uzorak istraživanja odabrane su ukupno 34 države od kojih 28 članica EU-a i 6 država JI Europe (Albanija, Bosna i Hercegovina, Crna Gora, Kosovo, Makedonija i 
Srbija). Istraživanja fokusirana na bankovnu stabilnost i utjecaj sustava osiguranja depozita relativno su oskudna u navedenom prostornom i vremenskom obuhvatu, posebice za države II Europe.

\section{1 Definiranje uzorka i varijabli znanstvenog istraživanja}

U odnosu na dosadašnja znanstvena istraživanja, u ovom istraživanju osim komercijalnih banaka zastupljene su i ostale kreditne institucije koje participiraju unutar sustava osiguranja depozita u ovisnosti o zakonskom okviru pojedine države. Podaci o bankama i ostalim kreditnim institucijama preuzeti su iz komercijalne baze podataka Bankscope, Bureau van Dijk. ${ }^{4}$ Nakon izostavljanja institucija s nedostajućim podacima, konačni broj zastupljenih aktivnih institucija u analizi je 1453, od čega je 809 komercijalnih banaka te 644 ostalih kreditnih institucija koje participiraju unutar sustava osiguranja depozita. S obzirom na definiranu hipotezu i nepostojanje jednoznačne definicije bankovne stabilnosti, ista se aproksimira kroz varijable bankovnog rizika (preuzimanje rizika). Bankovni rizik izražava se uz pomoć dvije zavisne varijable (Laeven, Levine, 2009; Angkinand, Wihlborg, 2010; Forssbaeck, 2011; Lè, 2013; Anginer et al., 2014; Hasan et al., 2017; Lambert et al., 2017): z-score-a te udjela nenaplativih kredita u ukupnim kreditima (NPL).

Z - score je mjera bazirana na solventnosti i profitabilnosti. Izračunava se pomoću rolling window analize (u ovome istraživanju za $3 \mathrm{~g}$.) kao zbroj povrata na aktivu i omjera kapitala i ukupne imovine u odnosu na standardnu devijaciju povrata na aktivu. Veća vrijednost z-score-a predstavlja veću stabilnost, odnosno manju rizičnost banaka. Zbog iskrivljene vrijednosti tradicionalnog z-score-a, u modelu se koristi njegova logaritmirana vrijednost kojom se postiže normalna distribucija (Laeven, Levine, 2009; Beck et al., 2013; Arouri et al., 2014). Nenaplativi krediti prema Li-u (2003) predstavljaju nepoželjne bankovne troškove smanjujući bankovne performanse te ih je zbog negativnog utjecaja na poslovanje pojedine banke i bankovnog sustava potrebno kontrolirati. Nenaplativi krediti najčešće rastu u vrijeme krize, a opadaju za vrijeme prosperiteta, iako se tada i stvaraju jer većina nenaplativih kredita iz budućih kriznih razdoblja odobrena je upravo u vrijeme prosperiteta (Sinkey, Greenawalt, 1991). Nezavisne varijable korištene u modelima odnose se na specifična obilježja sustava osiguranja depozita te dostignut makroekonomski razvoj. U istraživanju su zastupljene i dummy varijable koje predstavljaju pokazatelje (ne)članstva u EU-u čime se nastoji ispitati rizičnost bankovnih sustava.

\subsection{Metodologija znanstvenog istraživanja}

$\mathrm{U}$ ovome znanstvenom istraživanju analiza podataka provedena je statističkim programom STATA te je zbog dinamičke prirode ekonomskih relacija korištena dinamička panel analiza. Za potrebe modela koristi se Arellano-Bondov (AB) procjenitelj u dva koraka (Arellano, Bond, 1991). Testiranjem modela Sargan testom utvrđeno je postojanje heteroskedastičnosti varijance te je $u$ analizi korištena verzija robusnih standardnih grešaka temeljem metodologije Windmeijer-a (2005) te Newey-a i Windmeijer-a (2009). Iste su testirane Waldovim testom te testom autokorelacije i pokazale ispravnost rezultata svih postavljenih modela.

4 Komercijalna baza podataka Bankscope, Bureau van Dijk baza bila je dostupna do kraja 2016. g. obuhvaćala je financijske podatke o 22000 bankovnih institucija (5 $900 \mathrm{u} \mathrm{EU}$ ). 
Model znanstvenog istraživanja specificira se kao:

$y_{i t}=\mu+\gamma y_{i, t-1}+\beta_{1} x_{i t 1}+\beta_{2} x_{i t 2}+\cdots+\beta_{K} x_{i t K}+\alpha_{i}+\varepsilon_{i t} ; i=1, \ldots N, t=1, \ldots T$.

(1)

$\begin{aligned} z-\operatorname{score}_{i, t}=\alpha+ & \gamma z-\operatorname{score}_{i, t-1}+\beta_{1} \text { lnlimit }_{i, t}+\beta_{2} \text { ADMINISTRATION }_{i, t}+\beta_{3} \text { PREMIA }_{i, t}+\beta_{4} \text { COINS }_{i, t} \\ & +\beta_{5} \text { INTERBANK }_{i, t}+\beta_{6} \text { FREIGNCUR }_{i, t}+\beta_{7} \operatorname{lnGDPPCAPITA}_{i, t}+\beta_{8} \text { CPIINDEX }_{i, t}+\beta_{9} \text { EUSTATE }_{i, t} \\ & +\varepsilon_{i, t} ; i=1, \ldots, 14530, t=1, \ldots, 10 .\end{aligned}$

(2)

$N P L_{i, t}=\alpha+\gamma N P L_{i, t-1}+\beta_{1}$ lnlimit $_{i, t}+\beta_{2}$ ADMINISTRATION $_{i, t}+\beta_{3}$ PREMIA $_{i, t}+\beta_{4}$ COINS $_{i, t}+\beta_{5}$ INTERBANK $_{i, t}$

$+\beta_{6}$ FREIGNCUR $_{i, t}+\beta_{7} \operatorname{lnGDPPCAPITA}_{i, t}+\beta_{8}$ CPIINDEX $_{i, t}+\beta_{9}$ EUSTATE $_{i, t}+\varepsilon_{i, t} ; i$

$=1, \ldots, 14530, t=1, \ldots, 10$.

(3)

\section{EMPIRIJSKA ANALIZA I INTERPRETACIJA REZULTATA}

Odabrani set podataka koristi se $u$ analizi s visokim stupnjem varijabilnosti. Panel je nebalansiran zbog nedostajućih podataka za pojedine varijable. Navedeno je rezultiralo manjim brojem opservacija i mogućoj pristranoj procjeni modela. Stoga se tehnika panel analize nametnula kao prihvatljivo rješenje za prevladavanje navedenih ograničenja.

Tablica 2. Rezultati panel analize utjecaja sustava osiguranja depozita na rizik banaka

\begin{tabular}{|l|c|c|c|c|}
\hline Zavisne varijable & z-score & NPL & z-score & NPL \\
\hline Nezavisne varijable & & & & \\
\hline \multirow{2}{*}{ Lagirana zavisna } & $0,574^{* * *}$ & $0,232^{*}$ & $0,412^{* * *}$ & $0,232^{*}$ \\
& $(0,060)$ & $(0,137)$ & $(0,073)$ & $(0,137)$ \\
\hline \multirow{2}{*}{ Inlimit } & $\begin{array}{c}0,062^{* * *} \\
(0,014)\end{array}$ & $\begin{array}{c}1,052^{* * *} \\
(0,357)\end{array}$ & $\begin{array}{c}0,032^{* *} \\
(0,015)\end{array}$ & $\begin{array}{c}1,052^{* * *} \\
(0,357)\end{array}$ \\
\hline \multirow{2}{*}{ ADMINISTRATION } & 0,024 & $-2,223$ & 0,034 & $-2,223$ \\
\hline \multirow{2}{*}{ PREMIA } & $(0,044)$ & $(0,379)$ & $(0,047)$ & $(0,379)$ \\
\hline \multirow{2}{*}{ COINS } & 0,036 & $0,617^{* * *}$ & 0,020 & $0,617^{* * *}$ \\
& $(0,028)$ & $(0,0002)$ & $(0,032)$ & $(0,0002)$ \\
\hline \multirow{2}{*}{ INTERBANK } & $0,155^{* * *}$ & $-0,278$ & $0,192^{* * *}$ & $-0,278$ \\
& $(0,057)$ & $(0,436)$ & $(0,033)$ & $(0,436)$ \\
\hline
\end{tabular}


S. Suljić Nikolaj, B. Olgić Draženović, S. Drezgić: Učinci sustava osiguranja depozita na bankovni rizik Zbornik Veleučilišta u Rijeci, Vol. 7 (2019), No. 1, pp. 69-82

\begin{tabular}{|c|c|c|c|c|}
\hline FOREIGNCUR & $\begin{array}{l}0,139^{* *} \\
(0,065)\end{array}$ & $\begin{array}{l}1,902^{*} \\
(0,980) \\
\end{array}$ & $\begin{array}{l}0,190^{* *} \\
(0,072)\end{array}$ & $\begin{array}{l}1,902^{*} \\
(0,980) \\
\end{array}$ \\
\hline InGDPPCAPITA & $\begin{array}{c}0,195^{* * *} \\
(0,049)\end{array}$ & $\begin{array}{c}-6,343^{* * *} \\
(1,890)\end{array}$ & $\begin{array}{l}0,117^{* *} \\
(0,049)\end{array}$ & $\begin{array}{c}-6,343^{* * *} \\
(1,890)\end{array}$ \\
\hline CPIINDEX & $\begin{array}{c}0,003 \\
(0,003)\end{array}$ & $\begin{array}{c}0,308^{* * *} \\
(0.056)\end{array}$ & $\begin{array}{c}0,278^{* * *} \\
(0,002)\end{array}$ & $\begin{array}{c}0,308^{* * *} \\
(0,056)\end{array}$ \\
\hline EUSTATE & $\begin{array}{c}-0,181^{* * *} \\
(2,947)\end{array}$ & $\begin{array}{r}0,074 \\
(0.971) \\
\end{array}$ & & \\
\hline NOEUSTATE & & & $\begin{array}{c}0,278^{* * *} \\
(0,068)\end{array}$ & $\begin{array}{l}-0,074 \\
(0.971) \\
\end{array}$ \\
\hline konstanta & $\begin{array}{c}-1,460^{* * *} \\
(0,441)\end{array}$ & $\begin{array}{c}23,646 \\
(16,990)\end{array}$ & $\begin{array}{c}-0,930^{* *} \\
(0,447)\end{array}$ & $\begin{array}{r}23,720 \\
(17,340)\end{array}$ \\
\hline$Z(1)$ & $-6,951$ & $-0,976$ & $-5,843$ & $-0,976$ \\
\hline$Z(2)$ & 0,051 & $-0,178$ & 0,341 & $-0,178$ \\
\hline Wald test & $222,15^{* * *}$ & $202,40^{* * *}$ & $263,81^{* * *}$ & $202,40^{* * *}$ \\
\hline Br. instrumenata & 46 & 46 & 46 & 46 \\
\hline Br. opažanja & 7216 & 2959 & 7216 & 2959 \\
\hline Br.banaka & 1331 & 811 & 1321 & 811 \\
\hline Stupanj & 2 & 2 & 2 & 2 \\
\hline
\end{tabular}

******* - signifikanost na razini $10 \%, 5 \%$ te $1 \%$

Izvor: izradili autori prema izračunima STATE/SE 13.0

Rezultati panel analize utjecaja sustava osiguranja depozita na rizik banaka ukazuju kako je iznos zaštite sustava osiguranja depozita (Inlimit) pozitivan i signifikantan varijablama bankovnog rizika. Veći iznos zaštite sustava osiguranja depozita sprječava destabilizirajući efekt povlačenja depozita iz banaka, dok s druge strane, eliminira učinkovitost tržišne discipline u nadgledanju preuzimanja rizika banaka. Iz razloga što je povećanje iznosa zaštite najvećim dijelom ostvareno pojavom financijske krize, opravdano je očekivati da će navedena mjera usmjerena na smanjenje panike među deponentima, rezultirati manjim rizikom banaka (z-score). Suprotno tome, nenaplativi krediti koje karakterizira rast u vrijeme financijske krize te nastanak (odobravanje kredita) u vrijeme gospodarskog prosperiteta, očekivano rastu s porastom iznosa zaštite sustava osiguranja depozita.

Rezultati predstavljenih panel modela dokazuju pozitivan odnos premije (PREMIA) sustava osiguranja depozita s nenaplativim kreditima (NPL). Prema tome, postojanje diferencirane premije s obzirom na rizik kreditnih institucija tzv. fer premija, povećava kreditni rizik banaka. Odnosno, ukoliko je ranija procjena predstavljenih parametara ukazala na veći rizik (slabija kvaliteta) 
bankovnog poslovanja na temelju kojeg je utvrđen (veći) iznos premije sustava osiguranja depozita, posljedica navedenog će u budućem kriznom razdoblju biti veći udio „loših“ kredita. Odnos između koosiguranja (COINS) i z-score-a pozitivan je i signifikantan što potvrđuje kako je postojanje koosiguranja od 2005. do 2008. g. ublažilo bankovni rizik mjeren z-score-om. S obzirom da koosiguranje sprječava nastanak moralnog hazarda potičući deponente da nadgledaju poslovanje banaka zbog dijela svojih depozita koji nisu u potpunosti zaštićeni, navedeni rezultat je u skladu s očekivanjem. Pokrivenost depozita u stranoj valuti (FOREIGNCUR) kao obilježje sustava osiguranja depozita smanjuje rizik mjeren z-score-om te povećanje rizik mjeren NPL-om. Ako je u pojedinim državama zastupljena funkcija pokrivenih depozita u stranoj valuti, najčešće se isplata depozita vrši u domaćoj valuti stoga postoji mogućnost valutnog rizika (Demirgüç-Kunt et al., 2014). Također, ukoliko se krediti odobravaju u navedenoj stranoj valuti pri promjeni tečaja dolazi do povećanja iznosa rata kredita što se može negativno odraziti na vraćanja kredita odnosno povećanje udjela nenaplativih kredita.

Suprotan rezultat u odnosu sa z-score-om prisutan je jer navedena karakteristika sustava osiguranja osim što potiće kreditne institucije na dodatni rizik, stvara i dodatnu zaštitu u uvjetima nestabilnosti što deponentima povećava povjerenje u bankovni sustav te djelovanje sustava osiguranja depozita. Bruto domaći proizvod po stanovniku (InGDPPCAPITA) signifikantan je i pozitivan sa z-score-om te negativan s udjelom nenaplativih kredita (NPL). Prema tome, porast BDP-a po stanovniku, rezultira smanjenjem bankovnog rizika mjerenog z-score-om i NPL-om. Loši krediti karakteristični su za razdoblje gospodarskog pada, a njihovo smanjenje ostvaruje se u uvjetima gospodarskog rasta stoga je navedeni rezultat u skladu s očekivanjem. Također, u vrijeme rasta BDP-a po stanovniku tj. ekonomskog prosperiteta, postoji manja mogućnost za bankovni neuspjeh što opravdava odnos navedene varijable sa z-score-om. Odnos između indeksa potrošačkih cijena (CPIINDEX) i udjela nenaplativih kredita (NPL) pozitivan je i signifikantan. S obzirom da prosječni porast CPI indeksa nije ostvaren zbog ekonomskog rasta država koje predstavljaju uzorak istraživanja, već je porast potrošačkih cijena značajno rastao u razdoblju financijske krize (od 2009. do 2012.) kada je kupovna moć građana oslabljena, a stopa nezaposlenosti povećana, u navedenim gospodarskim uvjetima očekivana je posljedica neredovitih otplata kredita. Varijabla koja predstavlja članstvo EU (EUSTATE) signifikantna je s varijablama bankovnog rizika, negativna u odnosu na z-score te pozitivna s NPL-om. Navedeni rezultat ukazuje kako članstvo EU povećava rizičnost banaka što je i očekivano s obzirom na pojavnost bankovnih kriza u pojedinim zemljama EU-a (2008. - 2012.). Ipak, bankovni sustavi II Europe u istom razdoblju pokazali su se relativno stabilnim, za razliku od razdoblja od 1995. do 2005. g. koje su bile obilježene nizom nestabilnosti bankovnih sustava u JI zemljama (Männasoo, Mayes, 2009). Kreditna ekspanzija i rizično poslovanje u razdoblju koje je prethodilo financijskoj krizi, rezultiralo je navalama na banke i insolventnošću pojedinih banaka članica EU-a. Rezultati s dummy varijablom koja se odnosi na države JI Europe (NOEUSTATE) suprotnog su predznaka (u odnosu rezultate s varijablom članstva - EUEUSTATE), u modelima bankovnog rizika, a signifikantni sa z-score-om. Odnosno, u modelima sa z-score-om, dokazan je manji rizik banaka država ne-članica EU-a. Navedeni rezultat u skladu je s očekivanjem te znanstvenim istraživanjima o nastanku i posljedicama nedavne financijske i bankovne krize. Bankovne krize u pojedinim državama EU-a nastale uslijed snažnog bankovnog rasta temeljem trgovine sekundarnim vrijednosnim papirima te derivatima (Grgić, Kordić, 2011). Za razliku od 
banaka članica EU-a, banke država JI Europe svoje poslovanje su temeljile na tradicionalnim proizvodima. To je onemogućilo opskrbu navedenih gospodarstava svježim novcem te pooštrilo kreditnu politiku navedenih banaka, no u državama JI Europe financijska kriza nastala 2008. g. nije rezultirala bankovnim krizama.

Obrazloženjem rezultata dinamičke panel, dokazana je postavljena hipoteza kojom se potvrđuje kako obilježja/karakteristike sustava osiguranja depozita utječu na njegovu funkcionalnost u postizanju bankovne stabilnosti izražene kroz razinu preuzetih rizika banaka.

\section{ZAKLJUČAK}

Sustav osiguranja depozita poznat je oblik zaštite deponenata i banaka (bankovnog sustava), no njegovo djelovanje može imati i negatne učinke na bankovnu stabilnosti, ovisno o obilježjima (formiranju) samog sustava te karakteristikama financijskog sustava države. Stoga je velik broj empirijskih istraživanja usmjereno na analizu pojedinih obilježja sustava osiguranja depozita.

Financijska kriza u Europi te bankovne krize u pojedinim članicama EU-a početkom 2008. g. dovele su do promjena u nacionalnim sustavima osiguranja depozita: povećani su iznosi zaštite, napušten je mehanizam koosiguranja te je veliki broj država uveo i dodatne oblike zaštite. Unatoč navedenim mjerama, pitanje bankovne stabilnosti posebice država EU-a bilo je ugroženo. Stoga je stvorena potreba za nastankom novog oblika zaštite bankovnog i financijskog sustava europskih država - bankovne unije. Poput članica EU-a, države JI Europe su povećale iznose zaštite u vrijeme krize kao oblik zaštite od nastanka panike deponenata i eventualnih povlačenja depozita iz banaka, no prema ostalim obilježjima njihovi sustavi nisu istovjetni poput sustava EU-a.

Empirijsko istraživanje provedeno na uzorku članica EU-a i odabranih država JI Europe za razdoblje od 2005. do 2014. g. (prije, za vrijeme i nakon krize) ukazuje kako je djelovanje sustava osiguranja depozita na bankovnu stabilnost mjerenu preuzimanjem bankovnog rizika (z-score, udio nenaplativih kredita u ukupnim kreditima) u ovisnosti o pojedinim obilježjima sustava.

S obzirom na nedostatak empirijskih istraživanja o sustavima osiguranja depozita članica EU-a, a posebno država JI Europe, za buduća znanstvena istraživanja preporuka je istražiti učinke sustava osiguranja depozita u uvjetima budućih financijskih kriza posebno nakon uvođenja bankovne unije.

\section{NAPOMENA}

Ovaj rad je financiran sredstvima Sveučilišta u Rijeci za projekt ZP UNIRI 3/17.

\section{LITERATURA}

Acharya, V. V., Santos, J. A. C., Yorulmazer, T. (2010) Systemic Risk and Deposit Insurance Premiums, Federal Reserve Bank of New York Economic Policy Review, p. 89-99, https://pdfs.semanticscholar.org/92c3/6af16caed2399b75ecea6d01 40f4caa837f0.pdf (7.8.2018.) 
Anginer, D., Demirgüç-Kunt, A., Zhu, M. (2014) How does deposit insurance affect bank risk? Evidence from the recent crisis, Journal of Banking \& Finance, 48(1), p. 312 - 321. https://doi.org/10.1016/j.jbankfin.2013.09.013

Angkinand, A., Wihlborg, C. (2010) Deposit insurance coverage, ownership and banks's risk-taking in emerging markets, Journal of International Money and Finance, 29(2), p. 252-274. https://doi.org/10.1016/j.jimonfin.2009.08.001

Arellano, M., Bond, S. (1991) Some Tests of Specification for Panel Data: Monte Carlo Evidence and an Application to Employment, The Review of Economic Studies, 58(2), p. 277-297. https://doi.org/10.2307/2297968

Arouri, H., Muttakin, M. B., Hossain, M., Al Farooque, O. (2014) On the relation between internal corporate governance and bank risk taking: evidence from Gulf Cooperative Council countries, Academy of Taiwan business management review, 10(1), p. 91-100.

Beck, T., De Jonghe, O. Schepens, G. (2013) Bank competition and stability: Cross-country heterogeneity, Journal of Financial Intermediation, 22(2) p. 218-244. https://doi.org/10.1016/j.jf.2012.07.001

Blair, C. E., Carns, F., Kushmeider, R. M. (2006) Instituting a deposit insurance system: Why? How?, Journal of Banking Regulation, 8(1), p. 4-19. https://doi.org/10.1057/palgrave.jbr.2350038

Brandao-Marques, L., Correa, R., Sapriza, H. (2013) International evidence on government support and risk taking in the banking sector, Board of Governors of the Federal Reserve System, International Finance Discussion Paper, No. 1086, p. 1-53. https://doi.org/10.2139/ssrn.2328705

Calomiris, C. W. (1999) Building an Incentive-Compatible Safaty Net, Journal of Banking and Finance, 23(10), p.14991519. https://doi.org/10.1016/S0378-4266(99)00028-X

Calomiris, C. W., Wilson, B. (2004) Bank Capital and Portfolio Management: The 1930s "Capital Crunch" and the Scramble to Shed Risk, Joumal ofBusiness, University of Chicago press, 77(2), p. 421-456. https://doi.org/10.1086/386525

Cerović, Lj., Suljić Nikolaj, S., Maradin, D. (2017) Comparative Analysis of Conventional and Islamic Banking: Importance of Market Regulation, Ekonomska misao i praksa, 26(1), p. 241-263.

Chen, H. L., Chow, E. H., Liu, W. Y. (2014) The Determinants of Deposit Insurance Coverage: Evidence from 74 Countries, International Journal of Financial Research 5(4), p. 13-21. https://doi.org/10.5430/ijfr.v5n4p13

Chu, K. H. (2011) Depsoit Insurance and Banking Stability, Cato Journal, 31(1), p. 99-117.

Cull, R., Senbet, L. W., Sorge, M. (2002) The Effect of Deposit Insurance on Financial Depth: A Cross-Country Analysis, The Quarterly Review of Economics and Finance, 42(4), p. 673-694. https://doi.org/10.1016/S1062-9769(02)00120-5

Cull, R., Senbet, L. W., Sorge, M. (2005) Deposit insurance and financial development, Journal of Money, Credit and Banking, 37(1), p. 44-82.https://doi.org/10.1353/mcb.2005.0004

Davis, E. P., Obasi, U. (2009) Deposit Insurance Systems and Bank Risk, Economics and Finance Working Paper Series, Brunel University, No. 09-26, p. 1-40.

Demirgüç-Kunt, A., Detragiache, E. (2002) Does Deposit Insurance Increase Banking System Stability? An Empirical Investigation, Journal of Monetary Economics, 49(7), p. 1373-1406. https://doi.org/10.1016/S0304-3932(02)00171-X

Demirgüç-Kunt, A., Kane, E. J. (2002) Deposit Insurance Around the Globe: Where Does it Works?, Journal of Economic Perspectives, 16(2), p. 175-195. https://doi.org/10.1257/0895330027319

Demirgüç-Kunt, A., Kane, E. J., Laeven, L. (2007) Determinants of Deposit-Insurance Adoption and Design, The National Bureau of Economic Research, Working paper 12862, p. 1-74. https://doi.org/10.3386/w12862

Demirgüç-Kunt, A., Kane, E., Laeven, L. (2014) Deposit insurance database, IMF Working paper 14/118, p. 1- 44. https:// doi.org/10.5089/9781498354479.001

Diamond, D. W., Dybving, P. H. (1983) Bank runs, deposit insurance and liquidity, The Journal of Political Economy, 91(3), p. 401-419. https://doi.org/10.1086/261155

Direktiva 2014/49/EU, https://eur-lex.europa.eu/legal-content/hr/TXT/?uri=CELEX:32014L0049 (12.12.2016.)

Direktiva 94/19/EZ, https://eur-lex.europa.eu/legal-content/HR/TXT/?uri=celex\%3A31994L0019 (6.6.2015.) 


\section{S. Suljić Nikolaj, B. Olgić Draženović, S. Drezgić: Učinci sustava osiguranja depozita na bankouni rizik Zbornik Veleučilišta u Rijeci, Vol. 7 (2019), No. 1, pp. 69-82}

Fang, Y., Hasan, I., Marton, K. (2014) Institutional development and bank stability: Evidence from transition countries, Journal of Banking \& Finance, 39(1), p. 160-176. https://doi.org/10.1016/j.jbankfin.2013.11.003

Faulend, M., Kraft, E. (2004) Hrvatski sustav osiguranja štednih uloga: treba li ga mijenjati i ako treba, što promijeniti i kada?, Financijska teorija i praksa, 28(1), p. 121-139.

Fonseca, A. R., González, F. (2010) How bank capital buffers vary across countries: The influence of cost of deposits, market power and bank regulation, Journal of Banking \& Finance, 34(4), p. 892-902. https://doi.org/10.1016/j. jbankfin.2009.09.020

Forssbaeck, J. (2011) Ownership structure, market discipline and banks' risk-taking incentives under deposit insurance, Journal of Banking \& Finance, 35(10), p. 2666-2678. https://doi.org/10.1016/j.jbankfin.2011.02.024

Garcia, G. (1999) Deposit insurance: A Survey of Actual and Best Practices, IMF Working paper, 99/54, p. 1-49. https:// doi.org/10.5089/9781451847499.001

Goodman, L. S., Santomero, A. M. (1986) A Variable-Rate Deposit Insurance: a Reexamination, Journal of Banking and Finance, 10(2), p. 203-218. https://doi.org/10.1016/0378-4266(86)90005-1

Grgić, D., Kordić, G. (2011) Analogija krize zemalja s margine eurozone s krizom u Bosni i Hercegovini i Hrvatskoj, Ekonomska misao praksa, 10(1), p. 203-224.

Hasan, I., Fang, Y., Liu, L., Zhang, G. (2017) Deposit Insurance and the 2008-2009 Global Financial Crisis, Korea Deposit Insurance Corporation Financial Stability Studies, 18(1). https://doi.org/10.2139/ssrn.2999548

Iyer, R., Jensen, T., Johannesen, N., Sheridan, A. (2016) The Run for Safety: Financial Fragility and Deposit Insurance,http:// nielsjohannesen.net/wp-content/uploads/The-run-for-safety-full-paper-3May2016.pdf (19. 9. 2018.) https://doi. org/10.2139/ssrn.2780073

Khan, A. H. i Dewan, H. (2011) Deposit insurance scheme and banking crisis: a special focus on less-developed countries, Empirical Economics, 41(1), p. 155-182. https://doi.org/10.1007/s00181-010-0438-8

Kundid, A. (2013) Primjerenost kapitalnih zahtjeva za stabilnost bankarskog sektora, doktorska disertacija, Sveučilište u Splitu, Ekonomski fakultet, Split.

Laeven, L., Levine, R. (2009) Bank governance, regulation and risk taking, Journal of Financial Economics, 93(2), p. 259-275. https://doi.org/10.1016/j.jfineco.2008.09.003

Lambert, C., Noth., F., Schüwer, U. (2017) How do insured deposits affect bank risk? Evidence from the 2008 emergency economic stabilization act, SAFE Working Paper Series, 38. https://doi.org/10.1016/j.ff.2015.07.001

Lé M. (2013) Deposit Insurance Adoption and Bank Risk-Taking: the Role of Leverage, Paris School of Economics, Working Paper, 41, p. 1-38.

Lee, C. C., Hsieh, M. F. (2013) Bank reforms, foreign ownership, and financial Stability, Journal of International Money and Finance, 40, p. 204-224. https://doi.org/10.1016/j.jimonfin.2013.09.001

Li, Y. (2003) The Asian financial crisis and non-performing loans: Evidence from commercial banks in Taiwan, International Journal of Management, 20(1), p. 69-74.

Männasoo, K., Mayes, D. G. (2009) Explaining bank distress in Eastern European transition economies, Journal of Banking \& Finance, 33(2), p. 244-253. https://doi.org/10.1016/j.jbankfin.2008.07.016

Newey, W. K., Windmeijer. F. (2009) Generalized Method of Moments With Many Weak Moment Conditions, Econometrica, 77(3), p. 687-719. https://doi.org/10.3982/ECTA6224

Ngalawa, H. (2016) Banking instability and deposit insurance: the role of moral hazard, Journal of Applied Economics, 19(2), p. 323-350. https://doi.org/10.1016/S1514-0326(16)30013-7

Olgić Draženović, B., Kusanović, T. (2016) Determinants of capital market in the new member EU countries, Economic Research - Ekonomska Istraživanja, 29(1), p. 758-769. https://doi.org/10.1080/1331677X.2016.1197551 
Olgić Draženović, B., Živić, D., Vuković, M. (2017) Bankovna unija - mjera očuvanja fiskalne održivosti EU-a, poglavlje u Blažić, H., Dimitrić, M. i Pečarić, M. (ur.) Financije na prekretnici: Imamo li snage za iskorak?, In memoriam prof. dr. sc. Ivo Sever, Sveučilište u Rijeci, Ekonomski fakultet, Rijeka, p. 199-212.

Pennacchi, G. (2006) Deposit insurance, bank regulation and financial system risk, Journal of Monetary Economics, 53, p. 1-30. https://doi.org/10.1016/j.jmoneco.2005.10.007

Prohaska, Z., Suljić, S., Olgić Draženović, B. (2015) Sistem zavarovanja depozitov v državah EU (1), Bančni vestnik, 64(7-8), p. 50-55.

Rochet, J. C. (2008) Why Are there So Many Banking Crises? The Politics and Policy of Bank Regulation, Princeton University Press, New Yersey. https://doi.org/10.1515/9781400828319

Sinkey Jr. J. F., Greenawalt, M. B. (1991) Loan-loss experience and risk-taking behavior at large commercial banks, Journal of Financial Services Research, 5(1), p. 43-59. https://doi.org/10.1007/BF00127083

Suljić Nikolaj, S. (2018) Sustav osiguranja depozita u funkcije stabilnosti bankovnog poslovanja, doktorska disertacija, Sveučilište u Rijeci, Ekonomski fakultet, Rijeka.

Suljić, S., Vidmar, F., Prohaska, Z. (2014) Osiguranje depozita, poglavlje u Ćurak, M., Kundid, A., Visković, J. (ur.) Financije nakon krize: Forenzika, etika i održivost, Sveučilište u Splitu, Ekonomski fakultet, p. 167-186.

Windmeijer, F. (2005) A finite sample correction for the variance of linear efficient two-step GMM estimators, Journal of Econometrics, 126(1), p. 25-51. https://doi.org/10.1016/j.jeconom.2004.02.005 


\title{
THE EFFECTS OF THE DEPOSIT INSURANCE SYSTEM ON BANK RISK
}

\author{
Stella Suljić Nikolaj \\ PhD, Assistant, University of Rijeka, Faculty of Economics and Business, Ivana Filipovića 4, 51000 Rijeka, \\ Croatia; e-mail: stella.suljic.nikolaj@efri.hr
}

\section{Bojana Olgić Draženović}

PhD, Assistant Professor, University of Rijeka, Faculty of Economics and Business, Ivana Filipovića 4, 51000 Rijeka, Croatia; e-mail: bojana.olgic.drazenovic@efri.hr

\section{Saša Drezgić}

PhD, Associate Professor, University of Rijeka, Faculty of Economics and Business, Ivana Filipovića 4, 51000 Rijeka, Croatia; e-mail: sasa.drezgic@efri.hr

\begin{abstract}
Bank stability is based on the depositors' trust in banks and the entire banking systems. One of the basic measures that provides these is the deposit insurance system as an integral part of the security network of each financial system. Its importance is particularly pronounced in times of instability and crisis, while in "good times" their positive effects are underestimated. Nevertheless, the deposit insurance system has also resulted in negative consequences in terms of bank risk mitigation, reduced market discipline, moral hazard risk, negative selection and principal-agent problems. The aim of the paper is to examine the effects of the deposit insurance system on bank stability in the pre-global financial crisis period, the crisis period and the post-global financial crisis period. The bank stability is approximated by measures of bank risk (z-score, non-performing loans in total loans) and deposit volatility (total deposits and interest expense of deposits). The research has included all types of credit institutions (1453) of the EU states and some selected SE European countries. The analysis has been verified by dynamic panel data analysis - GMM Arellano-Bond ( $A B)$ estimator in two steps. The empirical analysis results indicate that the effect of the deposit insurance system on banking stability, measured by bank risks and deposit volatility, depends on the system characteristics, i.e. the applied system design, in view of institutional, historical and legal differences among countries.
\end{abstract}

Keywords: deposit insurance system, bank stability, risk, dynamic panel data analysis. 